\title{
Prezentacje
}

\section{Dziennik Émilie Serpin (1863-1881)}

Philippe Lejeune
Żródło: Philippe Lejeune, Le journal quotidien à Émilie Serpin „,Clio. Femmes, Genre, Histoire", $2012 \mathrm{nr} 35$, S. $147-163$.

TEKSTY DRUGIE 2018, NR 6, S. 161-173

DOI: 10.18318/td.2018.6.13

W 2006 roku przez uprzejmość przyjaciela nawiązałem kontakt z pewnym erudytą z Tours, który zastanawiał się, co zrobić z kolekcją zeszytów zakupionych u ulicznego sprzedawcy. Dobiliśmy targu. Będąc przejazdem w Paryżu, przekazał mi szesnaście zeszytów wypełnionych rękopiśmiennymi zapisami. Wyblakły atrament na stronie tytułowej oznajmiał na okładkach, że jest to Dziennik Emilii Serpin, poza tym, po lewej, widniały litery: „J.M.J.” Tak, chyba Opatrzność Boska z pomocą Jezusa, Marii i Józefa sprawiła, że zapiski Émilie trafiły w dobre ręce! Zdeponowałem je w Towarzystwie Autobiograficznym; zostały uratowane. Przede wszystkim jednak je przeczytałem! I stał się kolejny cud: ja, agnostyk, a nawet antyklerykał, nawróciłem się - co najmniej na Emilię! Ale może tak się stało, gdyż sama Émilie była wyznawczynią kultu dziennika? Jeśli spędzałem długie dnie bez wytchnienia, od świtu (gdyż atrament był wyblakły), aby przebrnąć przez owych 2000 stron,
Philippe Lejeune wybitny francuski znawca pisarstwa autobiograficznego; po polsku ukazały się m.in. dwa wybory jego tekstów Wariacje na temat pewnego paktu. O autobiografii (2001, 2007), „Drogi zeszycie...,",Drogi ekranie...," O dziennikach osobistych (2010), a także książka Napisać swoje życie. Droga od paktu autobiograficznego do dziedzictwa autobiograficznego (2018). 
dokonując transkrypcji części, to stało się tak dlatego, że dobrze widziałem, że Émilie, w samotności swego pokoju, znajdowała się na progu herezji, polegającej na przedkładaniu dziennika ponad Boga. Jesteśmy 24 grudnia 1865 roku... czy będzie ona świętowała Boże Narodzenie, w wigilię narodzenia Jezusa? Nie, będzie obchodziła urodziny swojego dziennika, rozpoczętego w Angers wieczorem w rozpaczy, dokładnie 24 grudnia 1863 roku. Ma wtedy 28 lat, obchodzi dzień Świętej Katarzyny', jest nauczycielką u księcia de la Baudire, zajmuje się jego trzema córeczkami i razem spędzają lato w Anjou, w zamku de Bouzill, a zimę w Paryżu.

24 grudnia (1865): „Upłynęły dwa lata, gdy pod tą samą datą, o tej samej godzinie, sama w moim małym pokoju w Angers, mając duszę pogrążoną w gorzkim bólu, nie wiedząc, gdzie znaleźć siły i odwagę, by walczyć przeciwko przeciwieństwom losu, przeciwko zmiennym kolejom życia, które obróciły się przeciwko mnie z furią i groźbami, powzięłam dziwne postanowienie: zebrałam kilka kartek papieru, zszyłam je, potem wzięłam pióro i rzuciłam na okładkę zeszytu kilka słów, które zdumiały mnie samą: Dziennik Émilie Serpin: to jest moje nazwisko, ale czym jest ów dziennik , który podjęłam się prowadzić każdego dnia? Dla ludzi, dla kogoś obcego, będzie to tylko zszywka papieru, zapełniona bazgrołami, w sam raz by ją rzucić w ogień albo wykorzystać na tutki do tytoniu; dla mnie jednak, i nie przesadzę tu, jeśli powiem, że to moja radość, moja pociecha, mój najmilszy sposób spędzania czasu. Kto by tak sądził, czytając te linijki często zapisane w złym humorze, cierpkie, świadectwa utraty nadziei i upadku ducha? O! A jednak się nie mylę! Smutki, o których piszę, ofiarowując je Bogu, stały się moimi radościami; doznałam pocieszenia odkąd wyraziłam zawarte w moim sercu słabości; mam więcej odwagi i czuję się mniej samotna, odkąd mogę w moim pokoju opisywać zdarzenia każdego dnia. Nie wiem, czy dla mojej duszy jest to korzyść, niestety! wydaje się, że nie i nie chcę obrażać Boga, lecz zaczynam trzeci rok. Jaki będzie? Wiesz dobrze, mój Boże, to mi starczy, ponieważ pragnę tylko tego, czego Ty chcesz! Więc mój dziennik zachowa moje imię i ja nie cofnę decyzji, by wiódł mnie zgodnie z najwyższą wolą, choć byłby to najpoważniejszy argument, by go porzucić".

Dwa lata później, gdy dziennik liczy już cztery lata, Émilie nie widzi w nim już zwykłego pocieszenia, być może czuje się winna,że wchodzi w konkurencję

1 św. Katarzyna uważana była za patronkę niezamężnych kobiet, we Francji w XIX wieku w dzień jej poświęcony tzw. stare panny jako Caterinettes nosiły korony [przyp. tłum.] 
z tym, co otrzymuje od Boga, ofiarując mu swoje troski, ale inspirację, którą otrzymała od samego Boga, a także od Jezusa, jej Zbawcy!

24 grudnia (1867) „Północ, niedługo północ!... I oto nadeszła rocznica moich codziennych zapisków; po raz czwarty ją obchodzę. O! Ileż przykrości wymazało się z mojego umysłu, odkąd je wyznałam mojemu dyskretnemu dziennikowi! Ileż łez zatrzymałam, biorąc pióro i pozwalając, by gorycz zmartwień, które mnie atakowały, upadła na kartki, podobnie jak zbyt ciężkie wspomnienia, błędy, których gorzko żałowałam i które mnie przerażały, odkąd papier posiadł moją tajemnicę! Bądź błogosławiony, dobry Boże, za tę myśl, którą mnie natchnąłeś, jeśli oczywiście pochodziła od Ciebie, za ten zamiar poczęty pewnego dnia pośród wielkiego zwątpienia, gdy wydawało się, że cała ziemia mnie opuściła. Papier, niewinny zeszyt stał się moją ucieczką, być może z Twoją pomocą, o Jezu, stanie się o moim Zbawcą?".

Powiedzmy więc: Émilie wierzy w swoje zapiski, ta wiara, która mnie urzekła, będzie najważniejsza w mojej prezentacji. Ale przede wszystkim trzeba przedstawić autorkę. Jej historia jest powieściowa, w pewnych momentach - teatralna, gdy los był szczególnie brutalny. Jej społeczne usytuowanie sprawiło, że mogła być dobrą obserwatorką i krytyczką życia na prowincji i w Paryżu w czasach Drugiego Cesarstwa. Jej dziennik jest wreszcie prawdziwą encyklopedią praktyk religijnych. Bohaterka powieści, świadek historii, dewotka? Ta stara panna oddana dewocji, wycieńczona migrenami, skończy jako matka licznej rodziny, będzie się ratowała tak długo jak to możliwe pisaniem. Jak to się stało, że jej dziennik, wiek później, wyląduje na tandecie? Dokumenty rodzinne całkowicie się rozproszyły. Dziennik zachował się przez cały wiek. Bez wątpienia rozmiary i sposób prezentacji zapisków wymusiły pewien respekt i ostatecznie zeszyty nie wylądowały na śmietniku.

Dziennik składa się z 17 zeszytów tego samego formatu $(15,5 \times 20 \mathrm{~cm})$, bardzo obszernych (od 102 do 188 stron), papier był cięty i zszywany przez autorkę, tytuł zawsze taki sam: „J.M.J” na górze po lewej, ,1-szy zeszyt” (td.) na górze po prawej i centralnie w trzech liniach tytuł: „Dziennik/intymny/ Émilie Serpin”. Zapisy są rzeczywiście codzienne, co najmniej do trzynastego zeszytu (od 24 grudnia 1863 do 21 lutego 1871 roku), Emilia usprawiedliwia się zawsze, gdy powraca do pisana po chwilowej przerwie. Brak zeszytów 14 i 15 (1871-1874), niestety, zapewne zostały wypożyczone przez przypadkowego czytelnika, który ich nie zwrócił. Zeszyty 16 i 17 (1874-1881) są coraz bardziej nieciągłe i widać, że pisanie dziennika zostało przerwane w 1881 roku, zeszyt 17 ma zapisane tylko 33 strony z 154 kart, jakie liczy. 
Rozpoczęcie dziennika w wigilię 1863 roku nie było początkiem zapisów Émilie. Wcześniej już prowadziła dzienniki, ale wszystkie zniszczyła. Żałuje tego i zajmuje się wprowadzeniem zapisu autobiograficznego, który wypełnia lukę między czasem jej narodzin w 1837 roku a rokiem 1863. Jest to przedmiotem dodatkowego zeszytu liczącego 89 stron, bez tytułu. Od urodzenia do 1881 (gdy więc miała 44 lata), całe jej życie zostało przez nią samą opisane.

Jej usytuowane społeczne jest związane także z przemianami wieku, czyli awansem klas niższych do poziomu burżuazji. Autorka nie mówi o swoich dziadkach. Jej ojciec, nauczyciel w Tours i w Bourgueil, następnie osiadł w Chinon, gdzie w tym samym czasie zajmował się drobnym handlem, który prowadziła jego żona. Émilie wraz ze swoją siostrą została oddana na pensję do zakonnic, gdzie była znakomitą uczennicą. Potem pomagała prowadzić rodzinny handel, który, niestety, podupadł. Rodzina wyprowadziła się więc z Chinon, by osiąść w La Chapelle-sur-Loire, gdzie ojciec był nauczycielem gminnym, ale w końcu, mimo pomocy parafii, uległ konkurencji szkoły otwartej przez siostry. Sama Émilie prowadziła swoją klasę i uregulowała swój status, zdając egzamin nauczycielski w 1859 roku. W maju-czerwcu 1856 roku obserwowała powódź na Loarze, o której w epicki sposób opowiada. W swojej młodości, jak sama opowiada, miała pogodny charakter i nieraz nazywano ją „Wielką śmieszką". Jej doświadczenia były źródłem radości, poza właściwą jej energią. W 1860 roku poznała młodego człowieka, Louisa Gurin, który pracował w La Chapelle w biurze inżyniera, pana Vergera. Skłonność wzajemna, zgoda rodziców, wreszcie narzeczeństwo pod koniec 1860 roku. Ale młody człowiek jest chory, bez wątpienia - gruźlica, będzie pielęgnowany przez rodzinę, pisze listy, ale wieści nie są dobre, potem nie pisze, co niepokoi dziewczynę, która nie oczekiwała milczenia. 7 czerwca 1861 roku zasięga informacji u jego siostry i dowiaduje się, że jej narzeczony nie żyje od siedmiu tygodni, o czym jej nie powiadomiono!

Wielki szok, przełom: Émilie decyduje się porzucić rodzinę. Zostanie pomocnicą nauczycielki w klasztorze w Angers. Ale oto ma lepszą propozycję: może zostać nauczycielką w szlacheckiej rodzinie La Guesnerie, aby dokończyć edukację małej Madeleine, 15-letniej. Przyjmuje posadę. Spędzają zimę w Angers, a okres letni w różnych zamkach, ale życie jest ciężkie, otoczenie nie ma dla niej „względów, jakie powinni mieć ludzie dobrze urodzeni”. Jest odpychana przez wierzchołek społeczeństwa, w trudnym położeniu, ale ciekawym, dzieląc życie państwa i służby domowej, widzi lub odgaduje wszystko. Jest jednak bardzo samotna, brakuje jej towarzystwa młodszej siostry, którą 
uwielbia, poza tym wciąż przeżywa żałobę po ukochanym. Pocieszenie znajduje w religii. Odnajduje w Angers przyjaciela Louisa ze szkoły, który został księdzem, ksiądz Guignard stanie się jej pocieszycielem i przyjacielem, ma więc jezuitę za przewodnika duchowego i spowiednika. Jej praktyki religijne nasilają się, wypełniają pustkę życia, dyktują rytm dnia, od mszy porannej po nieszpory i modlitwy wieczorne, a przede wszystkim odbudowuje relacje z innymi. Jednak pod koniec 1863 roku, Madeleine de la Guesnerie, siedemnastoletnia, jest gotowa, by „wejść w świat”, i nie potrzebuje dłużej nauczycielki, Émilie musi więc pożegnać się z posadą. Jaka będzie jej przyszłość? Wtedy właśnie, w malutkim pokoiku, który będzie musiała niebawem opuścić, nie wiedząc jeszcze, dokąd się udać, wieczorem 24 grudnia 1863 roku rozpoczyna, a raczej podejmuje na nowo pisanie dziennika. Pod koniec autobiograficznego zarysu, podsumowując dwa lata spęczone w rodzinie La Guesnerie, decyduje się, że „nie będzie odkrywać cudzych sekretów i obnażać ich błędów czy działań, które zasługiwałyby na naganę czy pogardę". Dyskrecja, łatwa, gdy dokonuje się podsumowania, będzie mniej przestrzegana w partiach codziennych zapisów.

Pod koniec miesiąca Émilie znajduje nową posadę, którą przyjmuje: zostaje nauczycielką trzech córeczek księcia de la Braudiere. Co prawda pojawia się trudność, trzeba opuścić Angers, gdyż rodzina spędza zimę w Paryżu, a przyjemniejsze pory roku w Anjou, w zamku Bouzill, w Malay. W tym drugim miejscu Émilie pozostanie siedem lat, od marca 1864 do kwietnia 1871 roku, cały czas kontynuując dziennik, poza krótkimi przerwami. Jej doświadczenia się poszerzają: odkrywa Paryż, zostanie zabrana do teatru (co być może jest grzechem!), jedzie także w 1866 roku do kąpieliska morskiego. Wciąż wątpi w swoją przyszłość, małżeństwo wydaje się poza zasięgiem, uczestniczy w dniu św. Katarzyny, gdyż jest już starą panną, czasem rozpatruje, czy nie wstąpić do klasztoru, a czasem zastanawia się nad następnym miejscem. Jeśli jej dziennik, który odzwierciedla wiernie jej życie duchowe i praktyki religijne, może czasem nużyć, wynagradzają to partie, gdy opuszcza teren religijny, by kreślić relacje społeczne, w których środku się znajduje. Dzieli życie państwa, je przy ich stole, ale także życie służby, której pisze listy. Widzi podszewkę i bieliznę, fasadę i kulisy, opowiadając o poszczególnych zdarzeniach, nie czuje się dłużej zobligowana do zachowania takiej rezerwy jak w partiach autobiograficznych. Negocjacje z pracodawcą w sprawie płacy stają się okazją do uwag prawie socjalistki, w każdym razie w tonie moralnie surowym. Egoizm, nieliczenie się z pracownikiem, brak konsekwencji ją oburzają. Jeśli chodzi o uczennice - te wypróbowują jej cierpliwość do ostatnich granic... O ile 
wyznania religijne są żarliwe, w widoczny sposób skierowane do niej samej, by się utwierdzić, o tyle relacje z życia codziennego są jasne i precyzyjne.

Życie jest nieprzewidywalne. Monotonna i pełna rezygnacji egzystencja mogła się przedłużać, nawet do końca życia, ale 3 listopada 1870 roku, gdy wojna trwała w pełni, niesłychane, niemal teatralne zdarzenie zmieniło jej los. „Cóż za chaos w mojej biednej głowie!", notowała nieraz (14 stycznia 1868 roku) w reakcji na małe, nieoczekiwane zdarzenia (ojciec Noury, jej opiekun jezuita, powrócił do Paryża! Wychodząc z kościoła la Madelaine, widziała mężczyznę, który przypominał jej Louisa, jej zmarłego narzeczonego!). Ale tym razem to rzeczywiście powieściowe: otrzymała propozycję małżeństwa od pana Verger, inżyniera, niegdyś - pracodawcy Louisa, sporo starszego od niej. Właśnie stracił żonę, przypomniał sobie o niej, pragnie ją poślubić! Ona go sobie w ogóle nie przypomina, on pamięta, że kiedy była mała, kiedyś przechodziła ulicą i go nie pozdrowiła! „Wydaje mi się, że to sen. W każdym razie bardzo dziwna rzeczywistość". Do pierwszego, decydującego spotkania doszło w Bouzill 11 grudnia 1870 roku, najpierw upadli na kolana w modlitwie, a potem rozmawiali cztery godziny i ona powiedziała: tak! Ślub, celebrowany przez pana de la Beraudiere, mera Melay, odbył się 18 kwietnia 1871 roku. Dawna stara panna niskiego pochodzenia stała się burżuazyjną żoną, następnie matką trojga dzieci (Maria, Józef, Elżbieta), zajętą troską o bliskich i dom, potem o edukację dzieci, niepokojoną pogarszaniem się stanu zdrowia starzejącego się męża (zmarł w 1883 roku). Jakaż szkoda, że zagubiły się zeszyty 14 i 15, poświęcone małżeństwu i pierwszym latom wspólnego życia. Od 1874 roku, gdy rozpoczyna się zeszyt 16, aż do zaprzestania zapisów w 1881 roku, wszystko się rwie, brak czasu dla prowadzenia zapisów dziennika, co wcześniej było tak wielką potrzebą...

Co zrobić z tymi dwoma tysiącami stron, na których płowieje atrament? Przede wszystkim trzeba było je zdygitalizować, aby je utrwalić i aby lektura była łatwiejsza, a dokument został zdeponowany w Towarzystwie Autobiograficznym (tam znajduje się pod sygnaturą APA 3143). Ideałem byłoby doprowadzić do transkrypcji. To mogłoby stać się podstawą wydania, co niewątpliwie nie jest możliwe w innej formie niż w postaci wyboru. Całość byłaby użyteczna przy badaniach, które sugeruje tekst - jak historia edukacji, historia i praktyki religijne, badania genderowe, historia lokalna, historia elit, życia w zamkach itd., jest to kopalnia wiadomości dla historii społecznej i historii mentalności. Ja chciałbym po prostu, jako wstęp do przyszłych badań tego typu czy edycji, przywołać kilka cytatów, które mnie najbardziej poruszyły, a które są świadectwem wiary w samo pisanie, jaką 
żywiła Émilie Serpin, oraz jej talentu, który dowodzi, że stała się pisarką o czym zawsze marzyła.

W środku jej świata, jej „pokoik”, w którym lubi znaleźć się sama, by pisać. „Muszę oddać się pisaniu, ponieważ nie mam z kim pożartować" (3 lutego 1866). Ta sama potrzeba wykroczenia poza samotność popycha ją ku religii i ku zeszytowi. To się miesza, a więc: jej zeszyt wypełnia się modlitwami i wyznaniami modlitewnymi, pod znakiem Jezusa, Marii, Józefa, ale w kościele, odwrotnie, odbiera mowę jako dzieło sztuki, oczekuje przedstawień, które ocenia pod względem jakości, mówi o swojej przyjemności słuchania, porównuje talent krasomówczy kaznodziejów, dokonuje streszczeń, rozwija swoje wrażenia, rywalizuje (umiarkowanie!) z mówca, przechodząc od odbioru do twórczości. Odnajdziemy u niej, w każdej dziedzinie, pragnienie zajęcia miejsca artysty czy twórcy. Pisała we wstępie do swego dziennika: „Śmiejemy się z politowaniem, dostrzegając w tych linijkach objawiającą się wszędzie niezręczność autora, ale moja przesadna duma będzie chronić mnie przed ośmieszeniem" (24 grudnia 1863). A więc uspokaja ją nie tyle chrześcijańska pokora, co wyraźna duma.

W kościele, podobnie jak kazaniami, delektuje się muzyką. To jedna z rzeczy, które podziwia w Paryżu, choć miasto odbiera jako horror. Muzyka jest w Paryżu piękna. W Melay „śpiewaczki śpiewają bardzo rzadko i dobrze robią, bo to zachęca do ucieczki; ich wiejskie gardła są nieoszlifowane i wydają z siebie tylko krzyki. Pan proboszcz i wikary są antymuzykami i nie mają pojęcia o głosach..." (15 sierpnia 1864). W Paryżu, prawdziwa amatorka, rozróżnia kościoły: „Nigdy nie zawiodłam się na wizycie u świętego Rocha, nieszpory śpiewa się tam doskonale, zwłaszcza Salve Regina sprawiło mi ogromną przyjemność, chłopiec, który miał 13 albo 14 lat śpiewał solo, a jego głos był zachwycający, o nieprawdopodobnej słodyczy, potem chór śpiewał Alleluja na głosy, to było bardzo dobre" (2 kwietnia 1864). Ale prawdziwe rozkosze są w jej parafii, u św. Klotyldy, i rozpoznajemy, że miała dobry gust, od 1859 roku organistą był tu nie kto inny tylko Cesar Franck. „Muzyka św. Klotyldy jest zawsze piękna, ale dziś przeszła samą siebie, harfa i inne instrumenty, które naprawdę współbrzmią z organami w dni świąteczne dają cudowny efekt” (16 kwietnia 1865). „Była procesja z św. Sakramentem i z muzyką; bezwiednie poleciały mi z oczu łzy. Jaka zgoda, jaka harmonia, melodyjna harfa, piękne organy z ich tysiącem dźwięków głębokich i rozłożonych, basy, a przede wszystkim piękne głosy chóru z naszej parafii miały tego wieczora coś niebiańskiego" (3 lutego 1866). Ona sama także lubiła śpiewać, usiłowała czasem w samotności: 
28 grudnia (1863) „O, ukochana samotności! jakże cię błogosławię, wciąż bardziej! Tu, sama z Bogiem, zawsze w jego obecności, z rozkoszą oddaję się moim zatrudnieniom: modlę się, czytam, piszę, czasami śpiewam. O, moje śpiewanie nie jest ani melodyjne, ani harmonijne, natura odmówiła darów, w jakie wyposażyła hojnie wielu innych..."

Od swego przybycia do Paryża Émilie czuje się winna, jeśli idzie do teatru (co jest rzadkie), ale nie wyrzuca sobie opery włoskiej; uważa, że to nie grzech, gdyż nie rozumie słów i śledzi wyłącznie muzykę. Po wysłuchaniu Lunatyczki Belliniego, gdzie muzyka była „wyborna” (26 marca 1866), przyjmuje komunię ze spokojem duszy, nie czując potrzeby powtórnej spowiedzi. Włoski pozostaje poza zasięgiem, a muzyka oczyszcza wszystko.

W przeciwieństwie do muzyki, lektura rodzi problemy. Dzięki Bogu przewodnikiem Émilie jest pismo, które abonuje, „Messager du Sacre-Coeur de Jesus" (Biuletyn comiesięczny apostolatu modlitwy). Te zszywki, 6o-stronicowe formatu oktawy zajmują się różnymi formami pobożności: głębokie artykuły, aktualna kronika, biografie świętobliwe, czasami wiersze, informacje z misji, różności itd. Gdy ona prosi o radę ojca Noury, swego spowiednika i przewodnika duchowego, jezuitę, on pozwala jej na lekturę, ale ostrożną, Wyznań św. Augustyna (z zachowaniem rezerwy). Zapytany o powieści Walter Scotta, oświadcza, że da się je czytać, ale są bezwartościowe. Zaleca jej biografie pobożne, historię proboszcza z Ars, świętej Elżbiety Węgierskiej, żywot ojca Ravignan. Jednakże ona je już czytała! Podobnie jej czytała żywoty świętych z Anjou, Les Chouans, Siostrę Fabiolę i inne tego typu. Trzeba było przestudiować katalog biblioteczny, żeby odnaleźć tytuły, które pożycza i które są jej zalecane. Czytała np. Rokwżyciu kobiety Zenaidy Floriot, powieść w formie dziennika, której akcja rozgrywa się właśnie w Anjou. Bardzo poruszona czyta księdza Louisa Chevojon Wspomnienia zmartych czy Jak przebyć czyściec, myśląc zapewne o jej zmarłym Louisie (29 czerwca 1864). Z kazalnicy księża rzucają gromy przeciwko powieściom, które „święty Jeremiasz nazwał przyjęciem u diabła" (16 października 1864) i przeciwko Życiu Jezusa Renana, każą mieć się na baczności przed złymi książkami „tak dobrze napisanymi, że kształtują gust i styl". Argument przeciwko zgubnym wpływom: istnieją dobre książki, o podobnej wartości i je należy traktować jako wzór.

Émilie dzielnie żywi się tymi pobożnymi lekturami. Niektóre książki wychodzą poza swoje przeznaczenie, inspirują ją w sposób bardziej osobisty, wprawiają w zachwyt lub melancholię, gdy spotyka dzieła, które sama chciałaby napisać. Gatunkami, w których chciałaby się wyrazić, są poezja liryczna i dziennik intymny. 
Pod koniec lipca 1874 roku jest ona w trakcie kończenia pracy nad „wyborem wierszy wybranych"i oto jej przemyślenia zainspirowane lekturą Victora Hugo i Lamartine'a:

„19 sierpnia [1864] ... Właśnie skopiowałam wybór najpiękniejszych wierszy, który przygotowałam dla siebie. Modlitwa dla wszystkich Victora Hugo, znakomicie skomponowana. O! Któż mógłby podejrzewać, że serce, które podyktowało te wersy, jedynie z nazwy było chrześcijańskie? On wierzy w Boga, dowodzi tego, pisząc modlitwę dla wszystkich; wyznaje, że Bóg jest wielki i dobry i jest naszym ojcem; poleca łasce zmarłych i pragnie, by modlitwa ją dla nich wyjednała. [...] Pan Lamartine także napisał piękne wiersze religijne, choć on także nie był religijny. Cóż jednak piękniejszego można przeczytać niż Krucyfiks. Czyta się go w poczuciu wielkiego szczęścia i nigdy to nie nuży. Te medytacje religijne są wspaniałe. Bardzo żałuję, że nie umiem napisać o wszystkim, co mi przychodzi na myśl. Tak bardzo chciałabym wyrazić pięknymi wierszami każde z ważniejszych wydarzeń mojego biednego życia".

Zdarzały jej się więc próby rymowania, mamy tego poruszający dowód pod koniec pierwszego zeszytu, gdy powiedziawszy mu prozą: żegnaj!, mówi to jeszcze raz w wersach. Widać, że nie zachowuje w pełni reguł prozodii, ale jesteśmy pod wrażeniem tego pokazu, w którym łączą się jej dwie pasje, poezja liryczna i intymne wyznanie dziennika.

Inną lekturą, która głęboko poruszyła Émilie, były cztery tomy panny Monniot Le journal de Marguerite (1858, w dwóch tomach) i Marguerite a vingt ans (1861, dwa tomy), jeden z bestsellerów literatury dla panien drugiej połowy XIX wieku.Ta książka wzbudziła admirację i zazdrość wielu pokoleń młodych diarystek: jest tak dobrze napisana, skomponowana w sposób poruszający, że w porównaniu z nią własny dziennik wydawał się niczym. Także Émilie dotknęło to uczucie zazdrości: „Mojemu biednemu dzienniczkowi daleko do tej książki; jakże to jest świetnie napisane i jak wspaniale się czyta!" (21 lipca 1864). Dwa dni później przeżywa już tak wielkie zwątpienie, że chciałaby wszystko spalić: „Nie umiem nadać mojemu dziennikowi tej wagi, jaką daje lektura Journal de Marguerite, więc po co się nim zajmować! Wiele osób jak ja sporządza codzienne podsumowania dnia, zapisuje, co się im przydarzyło; jedynie, co jest mi właściwe - to głupia maniera, jaką przyjęłam. Miałam wiele razy ochotę spalić te zeszyty [...]" (23 lipca 1864).

Lektura Journal de Marguerite znowu rozbudziła w niej ból, że nie jest pisarką, który wyrażała już wiele razy w swoim dzienniku, począwszy od przybycia do zamku Bouzill, w początkach czerwca 1864 roku. „Zdecydowanie nie mam talentu literackiego" (10 czerwca 1864) wzdycha autorka, podejmując próbę 
opisania swoich spacerów na wsi. A potem, oto tak mówi o kąpielach morskich... jaka szkoda, że nie jest poetką!

8 lipca [1864] - „Wydaje się pewne, że pojedziemy, by brać kąpiele morskie; czy będę mogła się dołączyć? Nie wiem. To musi być zachwycający spektakl nad oceanem, kreśli się tak wspaniałe obrazy, że od dawna chciałam się tym cieszyć; ale wszystko, co nowe, jest dla mnie nowym powodem zawodu i goryczy. Dlaczego sama miałabym się cieszyć? Dlaczego, będąc pozbawioną talentu potrzebnego, aby je przedłużyć moim piórem, opisując je, utrwalając wierne wspomnienia, które mogłyby mnie cieszyć i zainteresować moich przyjaciół? Te dwa obciążenia są tak bolesne, że trudno to sobie nawet wyobrazić. Pisanie było moją ambicją. O, gdybym potrafiła pisać! Gdybym nie była tak głupia, gdybym była poetką! Jak wspaniale przeżywałabym chwile. Ale skąd się bierze to pragnienie, czyż nie jest to spowodowane chęcią przyciągnięcia uwagi, przeżycia chwały, zdobycia pewnej sławy? Mój Boże, sama tego nie wiem, ale w to wierzę. Cóż za absurdalne szaleństwo!".

Następnie próbuje sobie wytłumaczyć, że powinna dziękować Bogu, że nie obdarzył jej żadnym szczególnym talentem! Émilie nie była co prawda poetką, ale nie ma wątpliwości, że była pewnego rodzaju pisarką. Jej dwa główne zajęcia, w jej pokoiku, w jej azylu, to pisanie listów i dziennika. Spędzała godziny, pisząc listy - przeważnie listy innych. Jej biegłość, a także chrześcijańska miłość bliźniego sprawiały, że była na zawołanie wszystkich domowników, którym oddawała pisarskie usługi. Od wieku 15 lat, w Chinon, stała się swego rodzaju pisarką publiczną, jak to określa, a więc musiała niestety pisać także do ludzi nie znanych jej osobiście, których spraw nie pojmowała! (31 sierpnia 1865). Jednakże robiła to ze szczerego serca, poruszona zmartwieniami ludzi w jej otoczeniu, niezdolnych prowadzić korespondencji (10 sierpnia 1865). Już na swój własny rachunek, pisała ogromne listy do swoich bliskich (szczególnie do księdza Guignard i do swojej siostry Celestyny). Ale najintensywniejszy, regularny, ale i problematyczny kontakt to listy do rodziny, rodziców, brata Alfreda, siostry Elizy i najbardziej kochanej - Magdaleny. Bolesnym punktem jest dla niej brak równowagi, jaki dostrzega w wymianie:

6 kwietnia [1864] „[...] W mojej relacji jest coś, co mnie dziwi: zawsze, gdy kogoś dotknie jakiś ból czy kłopot, pisze do mnie szybko o tym, a ja na nie przypominam sobie bym choć raz nie odpowiedziała, dodając odwagi, znajdując zdania najlepsze, by wyrazić jak przyjmuję każde nowe doświadczenie tego typu. I pięknie, ja także piszę o moich smutkach, moich bólach, ale bez odpowiedzi, nigdy ani zadania, ani wyrazu pochodzącego z serca. $\mathrm{O}$, nie robię 
im wyrzutów. Bóg pozwala na to, by mnie nauczyć nieść własny krzyż i cierpieć troski, nie mówię o tym nikomu, ale cierpię w moim wnętrzu".

Być może istnieje związek między tym brakiem reakcji, a tym, co ona mówi o sposobie redagowania listów, bardzo rozwlekłych... i być może onieśmielających?

2 sierpnia [1865] „[...] Napisałam długi list do Alfreda. Nie wiem, jak to się dzieje, ale ciągle piszę do wszystkich członków rodziny i zawsze zapełniam długie stronice, nie znajdując sposobu, by wszystko powiedzieć; zawsze coś pozostaje, choćbym pisała codziennie, zapełniając cały papier. I kończę z wrażeniem, że to bzdury albo rzeczy bezużyteczne i zrobiłabym lepiej, zachowując je dla siebie".

Nie skopiowała w dzienniku własnych listów, ale odkąd rozstała się z rodziną, od 1861 roku, zachowała prawie wszystkie otrzymane odpowiedzi, uporządkowane w jej sekretarzyku, „mam ich wielkie pakiety”, precyzuje (16 stycznia 1870). Te listy często mają żałobne obwódki : „Niestety! Śmierć przenika wszędzie, żałoba znaczy życie, o! jakże to smutne!”.

Ale oczywiście jej prawdziwym przyjacielem pod względem ludzkim i prawdziwym dziełem pod względem literackim pozostaje dziennik. Jak już sugerowałem na początku, że to zaangażowanie może być problematyczne ze względów religijnych: czy nie kocha ona zanadto swojego dziennika, czy nie przykłada zbyt wielkiego znaczenia do tego, co jej dotyczy? Czy jej dziennik rzeczywiście pomaga w samodoskonaleniu się, doskonaleniu w cnocie, że usprawiedliwia to uwagę, jaką mu poświęca? Zawsze, gdy zmienia zeszyt i każdego 24 grudnia, w dzień rocznicy rozpoczęcia dziennika, podejmuje ten problem. Nie, nie staje się lepsza, planowała, by pracować nad „dobrym i trwałym nawróceniem” (24 grudnia 1864), ale widzi, że nic z tego nie wyszło, ma nadzieję, że w następnym roku będzie lepiej. Później dodała do swojego dziennika wymiar profesjonalny, planuje „dziennik edukacji”: „Będę lepiej widziała, w czym nie dopełniłam moich obowiązków, gdzie nie skorygowałam moich błędów"... (3 marca 1866) i ta postawa była długo podtrzymywana. Prawdziwy zysk nie dotyczy jednak ani moralności, ani wymiaru zawodowego, jest natury psychologicznej: dziennik pozwala jej zachować równowagę, znosić samotność, rekompensować sobie uczucia. Pod koniec dziesiątego zeszytu jasno uświadamia sobie, że dziennik nie pozwala jej się doskonalić, pozwala jej się „utrzymywać”. Dziennik w gruncie rzeczy jest jak Bóg, który cię trzyma za rękę...

3 października [1868] „[...] Dzisiaj kończę ten zeszyt, jutro zacznę nowy; przywiązuję duże znaczenie do tego zwyczaju i jeśli czegoś żałuję, to tego, że 
nie zaczęłam wcześniej i że zniszczyłam kilka stron wyrwanych, gdzie moja dusza się wyraziła. Ponieważ odczuwam uczucia, muszę je wyrażać; ich rzucenie na papier czasem wystarcza dla uspokojenia siły wrażeń i nagle, mówiąc, widzę, że nie tracę czasu, używając ich; choć nie widzę, żebym robiła postępy na drodze cnoty czy świętości, niestety! nie, usiłuję je wyznać, ale kim bym się stała, gdyby nie zwyczaj codziennego przyglądania się sobie? Nie wiem, ta medytacja jest mi potrzebna, a więc trzeba to kontynuować".

Jedenaście lat później, po wielu doświadczeniach, podejmując przedostatni zapis w swoim dzienniku, następnie porzuconym, wyraża ostatnie podziękowanie dla swego zeszytu:

13 kwietnia [1881] „Jak przyjaciel pewny i oddany, jesteś moją ucieczką, mój drogi zeszycie!... Powracam do ciebie, gdy zdarzenia spadają na moją głowę. Nie przez zaniedbanie wydaje się, że cię opuszczam. Brak mi czasu aby odnaleźć się w sobie i dla siebie; moje zajęcia wypełniają czas i wyczerpują moje siły, tylko sam Bóg to widzi, ale starczy. Jestem tam gdzie Twoja najwyższa Wola mnie postawiła, mój Boże, a też, daleka od narzekań, o, akceptuję kielich i za przykładem mojego Zbawcy, wypijam go do dna".

To zdanie na koniec, albo prawie na koniec ostatniego zeszytu, nie moje. Chciałem tu oddać smak tekstu, który, mam nadzieję, pewnego dnia będzie dostępny do czytania, niewątpliwie oczyszczony z pewnej części wyznań modlitewnych, tak by wydobyć na światło dzienne los osobisty i świadectwo społeczne kobiety z ludu na temat klas wyższych. Badanie tego typu nieznanego rękopisu angażuje emocjonalnie. Czasem jesteśmy zafascynowani, jakbyśmy czytali powieść Balzaca. Czasem dystans wobec ideologii religijnej i politycznej Émilie wychodzi na wierzch. Z drugiej strony, to trudne by bez publikacji choć części materiałów odmalować pejzaż duchowy, jaki się poznało. Czasami, przyznaję, zdarzało mi się myśleć, że Émilie była głupia, a potem, że to ja byłem głupi. Przechodziłem kolejno przez fascynację, zakłopotanie, rozdrażnienie, wreszcie miałem tego dość, znowu byłem poruszony i poczułem się jej przyjacielem. W miarę lektury następowało przyzwyczajenie do życia razem. Podbiła mnie swoją szczerością, zrozumiałem, że jej autoperswazja pociągała za sobą dyskurs religijny, uwiodła mnie jej pasja pisania i klarowność dyskursu na temat dziennika. 


\section{Abstract}

\section{Philippe Lejeune}

UNIVERSITY OF PARIS NORTH

The Personal Journal of Émilie Serpin (1863-1881)

This article by Philippe Lejeune, prominent French scholar on women's personal journals and founder of the French Association pour l'autobiographie et le patrimoine autobiographique [Association for Autobiography and Autobiographical Heritage], focuses on the diary of Émilie Serpin, a humble governess. Lejeune discusses nineteenthcentury forms of female spirituality, Serpin's experience of music through Catholic rites, her sense of loneliness in the wealthy homes of her employers, as well as her religiosity. For Serpin, her journal is a substitute for a close friend. Her relationship to diary-writing and religion allows her to maintain a sense of self-worth, which is threatened by the circumstances of her life in wealthy homes. The diary ends when Serpin unexpectedly gets married.

\section{Keywords}

nineteenth-century French diary writing, personal journal, Émilie Serpin, private archive, Association pour l'autobiographie et le patrimoine autobiographique, Association for Autobiography and Autobiographical Heritage (France), nineteenth-century Catholicism, female spirituality 